\title{
NOWE WYZWANIA W ZARZĄDZANIU ŁAŃCUCHEM DOSTAW PRODUKTU TURYSTYCZNEGO
}

\author{
Magdalena Baryń \\ Politechnika Częstochowska \\ Wydział Zarządzania
}

\begin{abstract}
Streszczenie: Celem niniejszego artykułu jest przedstawienie wyzwań, jakie stoją przed koordynatorami i integratorami turystycznych łańcuchów dostaw w związku z dynamicznie zmieniającym się otoczeniem. Krótko scharakteryzowano sam produkt turystyczny, który swą specyfikę zawdzięcza pierwiastkowi usługowemu. Następnie przedstawiono zagadnienia turystycznego łańcucha dostaw i zarządzania nim z uwzględnieniem elementów mających największy wpływ na sprawność tego zarządzania. Wreszcie przedstawiono i scharakteryzowano dwa największe wyzwania w zakresie zarządzania łańcuchem dostaw produktu turystycznego, którymi są zmiana struktury łańcucha związana z rozwojem Internetu oraz niestabilna sytuacja geopolityczna i groźby zamachów terrorystycznych w miejscach recepcji turystycznej.
\end{abstract}

Słowa kluczowe: łańcuch dostaw produktu turystycznego, produkt turystyczny, turystyczny łańcuch dostaw

DOI: 10.17512/znpcz.2016.2.17

\section{Wprowadzenie}

Branża turystyczna jest dziedziną gospodarki, która mimo kryzysu ekonomicznego ostatnich lat odnotowuje w Polsce stały rozwój. Z danych Ministerstwa Sportu i Turystyki wynika, że wydatki w gospodarce turystycznej w Polsce w roku 2015 wyniosły 23,8 mld euro i były o ponad 6 mld euro wyższe niż w roku 2011 (Ministerstwo Sportu i Turystyki 2016, s. 1).

By jednak produkty turystyczne, a tym samym cała branża turystyczna, zaspokajały w pełni potrzeby i oczekiwania klientów, niezbędna jest współpraca przedsiębiorstw turystycznych biorących udział w ich tworzeniu. Mówiąc dokładniej: konieczne jest stworzenie zintegrowanego łańcucha dostaw produktu turystycznego i odpowiednie nim zarządzanie. Jest to zadanie o tyle trudne, że produkt turystyczny jest dobrem dość specyficznym, a większość jego cech wynika $z$ usługowego charakteru. $Z$ tego powodu zarządzanie łańcuchem dostaw takiego produktu również odbiega nieco od tradycyjnie rozumianego zarządzania łańcuchem dostaw i wymaga zwrócenia uwagi na nieco odmienne kwestie. Musi ono również sprostać innego rodzaju wyzwaniom.

Celem artykułu jest przedstawienie specyficznych uwarunkowań zarządzania turystycznym łańcuchem dostaw oraz elementów mających zasadnicze znaczenie dla sprawności tego łańcucha. Publikacja prezentuje również najważniejsze współczesne wyzwania w zarządzaniu łańcuchem dostaw produktu turystycznego, które związane są z rozwojem nowoczesnych technologii oraz dynamicznymi zmianami geopolitycznymi i ekonomiczno-społecznymi. 


\section{Specyfika zarządzania lańcuchem dostaw produktu turystycznego}

W centrum rozważań dotyczących przemysłu turystycznego bez wątpienia znajduje się produkt turystyczny, który jest przedmiotem wymiany na rynku turystycznym. C. Kaspar za produkt turystyczny uznaje komplet przedmiotów materialnych oraz usług, które są wykorzystywane lub konsumowane przez turystę w trakcie jego podróży (Fijałkowski 2003, s. 81).

Generalnie produkty turystyczne podzielić możemy na dwie główne grupy: produkty proste oraz produkty złożone. Produkty proste są pojedynczymi dobrami lub usługami, natomiast produkty złożone uzyskuje się przez połączenie dwóch lub więcej produktów prostych. Najpopularniejszą kategorię produktów złożonych stanowią pakiety turystyczne i to właśnie one będą przedmiotem dalszych rozważań.

$\mathrm{W}$ proces tworzenia produktu turystycznego zaangażowanych jest wiele przedsiębiorstw turystycznych, jak choćby: biura podróży, obiekty noclegowe, placówki gastronomiczne, przedsiębiorstwa transportowe czy zarządcy atrakcji turystycznych. Przedsiębiorstwa te są niezależnymi podmiotami, ich celem jest maksymalizacja własnego zysku, jednak ich działanie wymaga wchodzenia w wiele interakcji z innymi przedsiębiorstwami. Współpraca podmiotów z sektora turystycznego jest niezbędna, by można było w pełni zaspokajać potrzeby klientów i oferować im dokładnie to, czego oczekują. Współdziałanie to odbywa się właśnie w ramach łańcucha dostaw produktu turystycznego, przy czym im bardziej złożony produkt, tym więcej podmiotów zostaje do tej współpracy zaangażowanych.

Pomimo iż działanie turystycznego łańcucha dostaw jest w praktyce niezwykle istotne, w literaturze przedmiotu nie znajduje ono jeszcze należytego miejsca. Większość opracowań skupia się przede wszystkim na zagadnieniach dystrybucji oraz działań promocyjnych, pomijając znaczenie prawidłowej współpracy ogniw łańcucha dostaw produktu turystycznego. Tymczasem specyfika tego rodzaju łańcuchów sprawia, że zarządzanie nimi różni się od zarządzania łańcuchami dostaw innych, typowo materialnych produktów. Główna różnica polega na tym, że to klient podróżuje do miejsca konsumpcji produktu, a sam produkt złożony jest w dużej części z usług, co oznacza, że bardzo ważną rolę odgrywają w tym przypadku ludzie bezpośrednio świadczący usługi (Tapper, Font 2004, s. 3).

Sam łańcuch dostaw produktu turystycznego definiowany jest jako „sieć organizacji turystycznych zaangażowanych $\mathrm{w}$ dostarczanie różnych cząstkowych produktów i usług turystycznych, wykorzystywanych do tworzenia, a następnie dystrybucji gotowych pakietów turystycznych w miejscu recepcji turystycznej. Ogniwami tego łańcucha są podmioty sektora prywatnego i publicznego" (Zhang, Song, Huang 2009, s. 347).

Łańcuch dostaw produktu turystycznego obejmuje zatem wszystkich dostawców dóbr i usług, które składają się na produkty otrzymywane przez klienta. Składa się on $\mathrm{z}$ wielu komponentów - nie tylko zakwaterowania, transportu i wycieczek, lecz również z takich elementów, jak bary i restauracje, rzemiosło, produkcja żywności, usuwanie odpadów, czy też infrastruktura miejsca docelowego wykorzystywana przez turystów. Wszystkie te ogniwa tworzą produkt oczekiwany przez klienta w momencie zakupu. Dla klienta nie ma w tym przypadku znaczenia, czy 
ogniwa te są zakontraktowane przez touroperatora, czy też nie - wymaga on całościowego zaspokojenia swoich potrzeb (Tapper, Font 2004, s. 3-4).

Ogniwami, które w powszechnej opinii mają największe możliwości wpływania na kształt całego łańcucha dostaw, są, poza klientami, touroperatorzy. To właśnie touroperatorzy $\mathrm{w}$ większości przypadków pełnią rolę integratorów i zarządców poszczególnych turystycznych łańcuchów dostaw. Przedmiotem ich działalności jest bowiem zakup pojedynczych usług turystycznych (zakwaterowanie, transport, wycieczki), tworzenie z nich pakietów, a następnie dystrybucja - sprzedawanie gotowych produktów złożonych, których cena jest niższa niż suma cen usług cząstkowych. Poprzez łączenie popytu i podaży touroperatorzy odgrywają istotną rolę nie tylko w dystrybucji produktów, ale także ich promocji, ułatwiając jednocześnie wymianę informacji w turystycznym łańcuchu dostaw. Mają oni możliwość promowania lokalnych produktów i przedsiębiorstw, przez co są w stanie wspierać rozwój ekonomiczny obszaru recepcji turystycznej. Ogólnie rzecz ujmując, touroperatorzy mogą wpływać na wybory podróżujących, na strategie członków łańcucha dostaw oraz na plany rozwoju obszarów recepcji turystycznej, odgrywają zatem najistotniejszą rolę w kształtowaniu turystycznych łańcuchów dostaw (Sigala 2008, s. 1590).

Prawidłowe funkcjonowanie łańcucha dostaw produktu turystycznego nie jest jednak uzależnione jedynie od postaw i sposobu działania touroperatora. Istotnymi czynnikami są również struktura łańcucha (strategie, koncepcje, kanały dystrybucji, przewagi konkurencyjne itp.) oraz stosunki rynkowe między poszczególnymi ogniwami (np. między jednostkami żywieniowymi, obiektami noclegowymi, biurami podróży i turystami) (Tigu, Calaretu 2013, s. 106). Ogniwa te można podzielić na 6 głównych grup, którym odpowiadają poziomy łańcucha. Graficznie przedstawione zostało to na Rysunku 1.

Dostawcy II rzędu (np. dostawcy mediów, producenci żywności, dostawcy wyposażenia, dostawcy paliwa i części zamiennych) są jedynymi ogniwami, z którymi klient zwykle nie ma bezpośredniego kontaktu, jednak sprawność ich współpracy z dostawcami I rzędu ma duży wpływ na jakość końcowego produktu i satysfakcję klienta. W szczególny sposób ujawnia się to w sytuacjach negatywnych, gdy mamy do czynienia np. z dostawą nieświeżej żywności lub z przerwami w dostawie energii. Zdarzenia takie bardzo mocno wpływają na poziom zadowolenia klienta, mimo iż nie ma on bezpośredniej styczności $\mathrm{z}$ odpowiedzialnymi za to podmiotami. Chcąc skutecznie zarządzać łańcuchem dostaw produktu turystycznego, pamiętać zatem należy, iż jakość finalnych produktów dostarczanych klientowi zależy nie tylko od współpracy i jakości obsługi końcowych ogniw, lecz w dużej mierze również od funkcjonowania podmiotów, z którymi klient nie ma bezpośredniego kontaktu.

Samo zarządzanie turystycznym łańcuchem dostaw (w skrócie TSCM - Turist Supply Chain Management) może być definiowane jako ,zestaw metod wykorzystywanych do efektywnego zarządzania operacjami wykonywanymi w ramach turystycznego łańcucha dostaw. Operacje te dotyczą zaspokojenia potrzeb klientaturysty i mają się przyczynić do osiągnięcia celów biznesowych różnych przedsiębiorstw będących ogniwami łańcucha dostaw" (Zhang, Song, Huang 2009, s. 345). 
Filozofia TSCM wymaga koordynacji działań organizacji w całym łańcuchu dostaw. Do skutecznego zarządzania każdym łańcuchem dostaw, w tym również łańcuchem dostaw produktu turystycznego, niezbędne jest partnerstwo i chęć współpracy, które warunkują możliwość integracji działań poszczególnych ogniw (Surowiec 2012, s. 93).

Usługowy charakter produktów turystycznych oraz ich specyfika mają ogromne znaczenie w kształtowaniu kluczowych aspektów zarządzania turystycznym łańcuchem dostaw. X. Zhang, H. Song i G.Q. Huang wyróżniają siedem takich kwestii, wiążąc je jednocześnie $\mathrm{z}$ wybranymi cechami charakterystycznymi produktu turystycznego. Powiązania te przedstawiono na Rysunku 2.

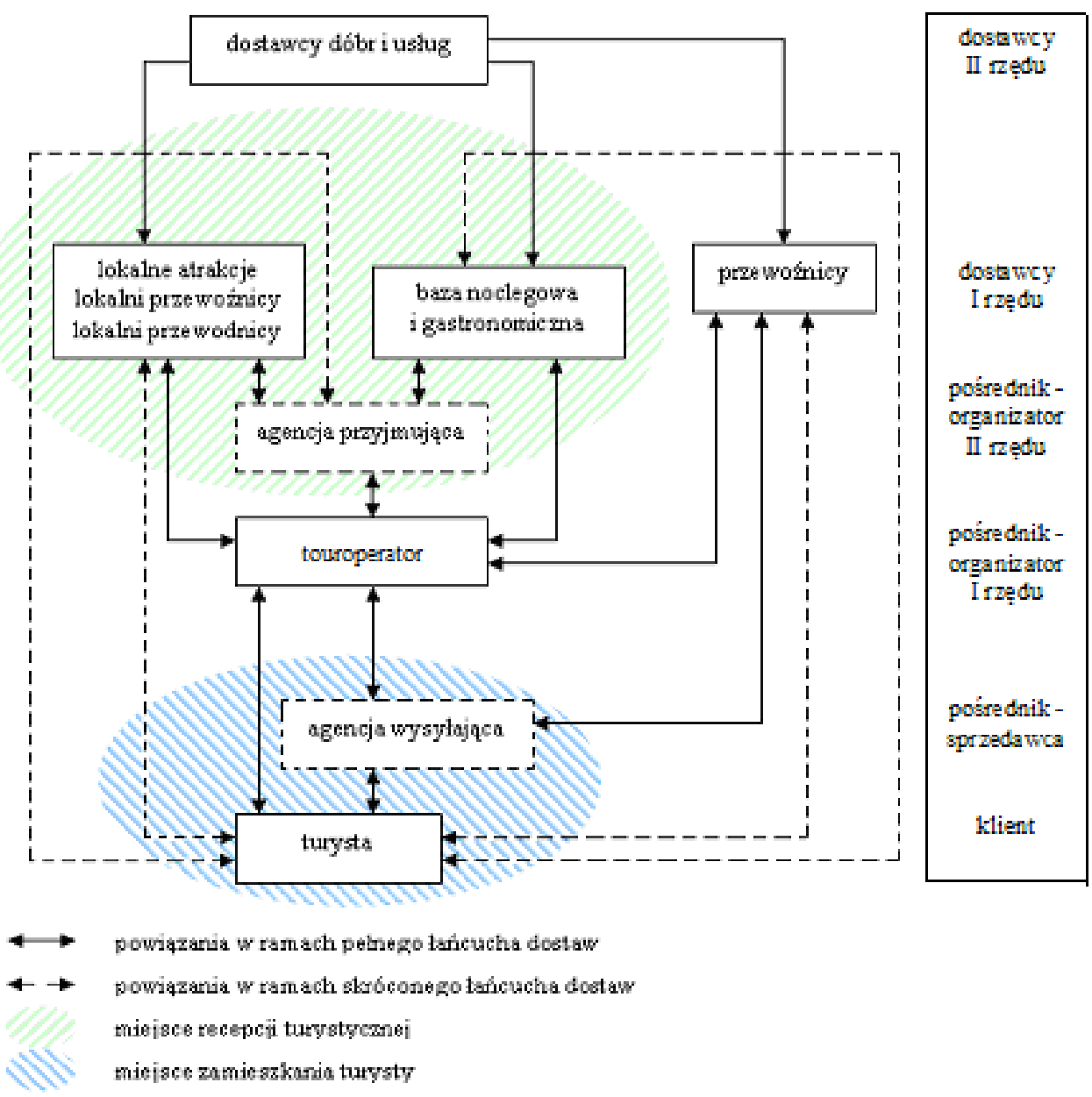

Rysunek 1. Lańcuch dostaw produktu turystycznego

Źródło: (Kusa 2009, s. 135) 


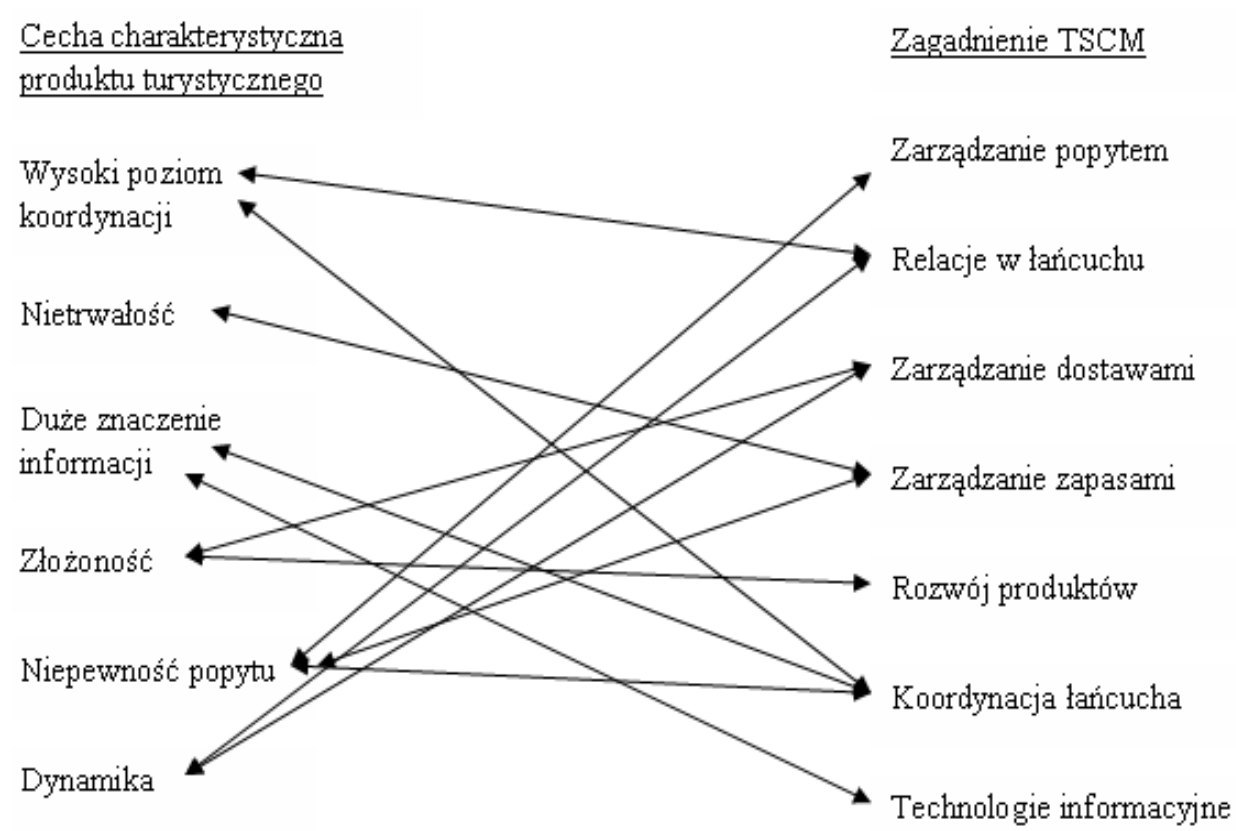

Rysunek 2. Powiązanie kluczowych kwestii turystycznego lańcucha dostaw z cechami charakterystycznymi produktu turystycznego

Źródło: Opracowanie własne na podstawie: (Zhang, Song, Huang 2009, s. 348)

Prawidłowe podejście wszystkich powyższych kluczowych kwestii jest niezbędne do efektywnego zarządzania turystycznym łańcuchem dostaw. Zaniedbania w którymkolwiek obszarze skutkować mogą obniżeniem jakości obsługi turysty i brakiem zaspokojenia jego potrzeb, a czasem nawet rozpadem łańcucha dostaw konkretnego produktu. Jednak obecnie, w obliczu nowych wyzwań związanych z zarządzaniem turystycznym łańcuchem dostaw, może się okazać, że nawet skuteczne działanie w tych siedmiu kluczowych obszarach nie gwarantuje sukcesu.

\section{Rozwój Internetu jednocześnie szansą i zagrożeniem dla tradycyjnych lańcuchów dostaw}

Szybki rozwój Internetu, jaki ma miejsce od lat dziewięćdziesiątych ubiegłego stulecia, w dużym stopniu zrewolucjonizował działanie wszystkich przedsiębiorstw, w tym również przedsiębiorstw z branży turystycznej. Pozwala on na bardzo szybką wymianę informacji, nawet między podmiotami znajdującymi się w odległych miejscach. Daje możliwość pozyskania informacji o towarach i usługach, ich selekcji oraz ewentualność wyboru najkorzystniejszej opcji. Rozwój sektora e-commerce otwiera szansę szerszej dystrybucji produktów, a internetowe płatności ułatwiają realizację zobowiązań (Ślusarczyk, Szajt 2013, s. 108). Dzięki temu nastąpił wzrost możliwości sprzedaży produktów turystycznych, a znaczna część przedsiębiorstw stworzyła własne witryny internetowe, ułatwiające komuni- 
kację zarówno z klientami, jak i innymi ogniwami turystycznego łańcucha dostaw. Wykorzystanie nowoczesnych technologii informacyjnych największe korzyści przyniosło właśnie $\mathrm{w}$ sferze dystrybucji produktów turystycznych oraz w sferze komunikacji i koordynacji działań między poszczególnymi ogniwami. Internet wykorzystywany jest w tym przypadku do reorganizacji bądź budowania na nowo powiązań między uczestnikami rynku turystycznego, a także stanowi przyczynę pojawiania się nowych graczy, którzy wcześniej na tym runku nie występowali (Buhalis 2008, s. 285-286).

Technologie informacyjne są wykorzystywane w branży turystycznej do realizacji takich zadań, jak:

- komunikacja z klientami i pozostałymi ogniwami łańcucha dostaw;

- prezentacja oferty przedsiębiorstwa turystycznego;

- rezerwacja usług turystycznych;

- sprzedaż usług i złożonych produktów turystycznych (Rapacz 2007, s. 152).

Wymienione wyżej zastosowania świadczą o pozytywnym wpływie rozwoju technologii teleinformatycznych, a zwłaszcza Internetu, na działalność zarówno poszczególnych ogniw turystycznego łańcucha dostaw, jak i łańcucha jako całości. Nie sposób jednak pominąć zagrożeń związanych z postępem technologicznym, choć to, co z perspektywy części ogniw łańcucha dostaw produktu turystycznego stanowi zagrożenie, w oczach ogniwa końcowego, czyli turysty, jawi się raczej jako szansa. Chodzi tu o możliwość samodzielnego konstruowania przez klienta pakietu turystycznego przy wykorzystaniu różnego rodzaju portali rezerwacyjnych umożliwiających zakup usług noclegowych, transportowych czy ubezpieczeń podróżnych bezpośrednio u dostawców tych usług. Turyści mogą dzięki temu stworzyć własny pakiet turystyczny dopasowany do ich potrzeb. Ma tu jednak miejsce wejście turysty $\mathrm{w}$ rolę touroperatora $\mathrm{i}$ wyparcie $\mathrm{z}$ łańcucha zarówno pośrednikaorganizatora, jak i pośrednika-sprzedawcy. Rozwój Internetu przyczynia się zatem w turystyce do ewolucji kształtu łańcucha dostaw produktu turystycznego i powstania drugiego typu tego łańcucha. Obok tradycyjnego łańcucha, w którym niezwykle istotną rolę odgrywają biura podróży - zarówno touroperatorzy, jak i pośrednicy oraz agenci turystyczni - pojawia się nowoczesny łańcuch oparty w dużej mierze na wykorzystaniu Internetu (zwłaszcza portali rezerwacyjnych), w którym rolę biur podróży przejmuje klient (łańcuch ten dla ułatwienia nazwać można elektronicznym łańcuchem dostaw produktu turystycznego).

Przy założeniu realizacji identycznego końcowego pakietu turystycznego kształt obu łańcuchów do pewnego momentu będzie zbieżny. Będą w nim bowiem występować jednakowi dostawcy I i II rzędu. Różnice pojawią się w nich na etapie organizatora, którego rolę $\mathrm{w}$ łańcuchu tradycyjnym pełni touroperator, natomiast w łańcuchu elektronicznym - sam klient. W łańcuchu elektronicznym nie będziemy mieć również do czynienia $\mathrm{z}$ tak dużą liczbą pośredników, jak w łańcuchu tradycyjnym, choć i tutaj pośrednicy mogą się znaleźć. Ich rolę pełnić mogą choćby portale rezerwacyjne typu Booking.com, Agoda.com czy Hotels.com. Mimo że w obu przypadkach ostatecznie uzyskamy taki sam pakiet turystyczny, to jednak jego łańcuch dostaw będzie wyglądał nieco inaczej. W łańcuchu elektronicznym biura podróży, czyli ogniwa tradycyjnie pełniące niezwykle istotną funkcję, zostają 
wyparte, a w ich miejsce mogą pojawić się inne ogniwa, bazujące głównie na wykorzystaniu narzędzi teleinformatycznych.

Różnice między dwoma formami turystycznego łańcucha dostaw łatwo można zobrazować, przedstawiając schematy łańcuchów przykładowego produktu turystycznego (Rysunek 3, Rysunek 4). Produktem tym będzie pakiet złożony $\mathrm{z}$ noclegu, przelotu samolotem, transportu z lotniska do hotelu oraz wycieczki do lokalnej atrakcji turystycznej. Elementem obowiązkowym każdego takiego pakietu jest również ubezpieczenie podróżne, dlatego ubezpieczyciel, jako ogniwo, zostanie uwzględniony w obu schematach. W pakiecie tym nie zostaną wzięte pod uwagę natomiast takie elementy, jak np. dostawcy pamiątek czy infrastruktura lokalna.

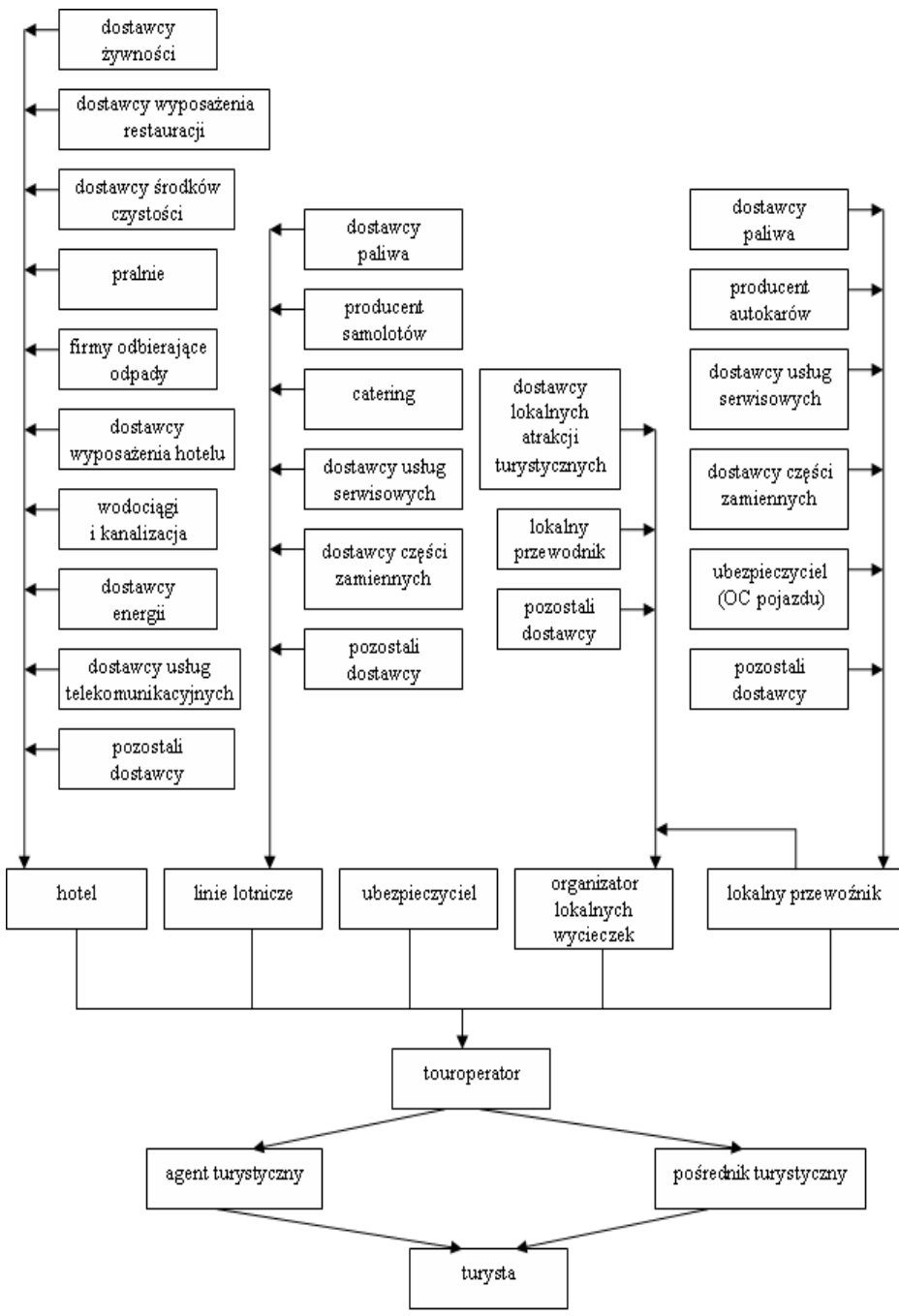

Rysunek 3. Uproszczony schemat przykładowego tradycyjnego lańcucha dostaw produktu turystycznego

Źródło: Opracowanie własne 


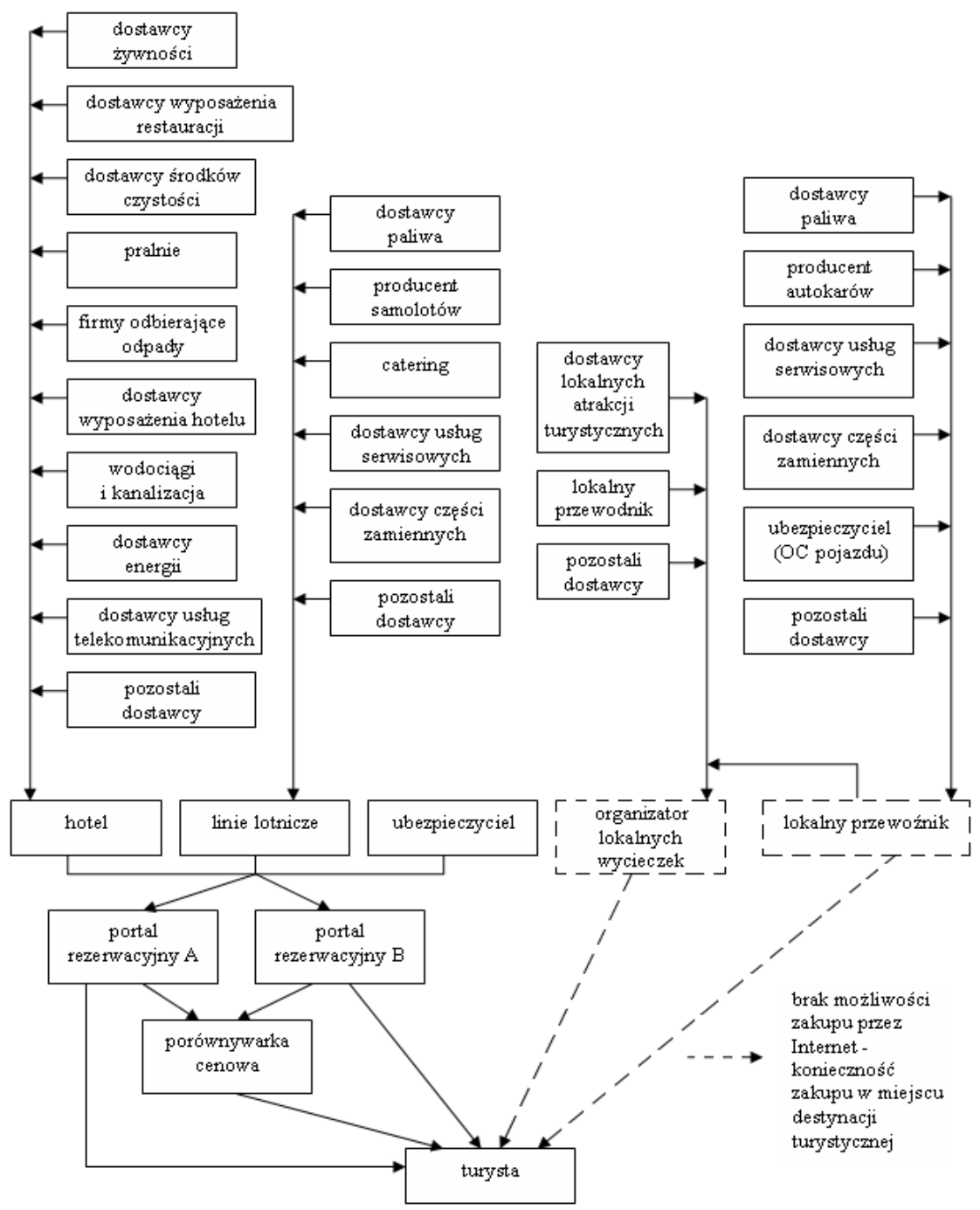

Rysunek 4. Uproszczony schemat przykładowego elektronicznego lańcucha dostaw produktu turystycznego

Źródło: Opracowanie własne

Powyższe schematy doskonale pokazują różnicę między tradycyjnym i elektronicznym łańcuchem dostaw produktu turystycznego, która to różnica uwidocznia się na poziomie kreatora pakietu - w łańcuchu tradycyjnym jest nim touroperator, natomiast w łańcuchu elektronicznym - klient. Oznacza to, że w tym drugim przypadku turysta odgrywa główną rolę nie tylko jako odbiorca wyrobu finalnego, w którego dostarczanie zaangażowane są ogniwa łańcucha dostaw, lecz również jako pełnoprawny twórca tego produktu. 
Przejęcie przez klienta roli touroperatora rodzi dwa podstawowe problemy funkcjonowania turystycznego łańcucha dostaw. Pierwszym jest ryzyko wyparcia z rynku turystycznego biur podróży, bowiem w sytuacji, gdy klient sam organizuje sobie pakiet turystyczny, biura te nie są już potrzebne, tracą zatem rację bytu. Mogą być one więc zmuszone do zakończenia działalności i zwolnienia pracowników. Drugie zagrożenie bezpośrednio wypływa $\mathrm{z}$ tego pierwszego, jednak dla sprawnego funkcjonowania łańcuchów dostaw produktu turystycznego, jak i całej branży może mieć ono znacznie poważniejsze konsekwencje. Pamiętając o tym, że to touroperatorzy $z$ reguły pełnią rolę integratora łańcucha dostaw $i$ jego swoistego zarządcy, trzeba zadać sobie pytanie, kto ma od nich przejąć tę rolę. Klient tylko jednorazowo zainteresowany jest danym pakietem turystycznym, nie będzie on zatem organizował działalności łańcucha dostaw tego pakietu w dłuższym czasie. Wykluczenie z łańcucha biur podróży, które koordynują współpracę między ogniwami, a także prognozują i napędzają popyt na dany pakiet turystyczny, może skutkować rozpadem całego łańcucha i spadkiem efektywności działania poszczególnych ogniw.

Rolę pełnioną $\mathrm{w}$ tradycyjnym łańcuchu przez touroperatorów mogą w pewnym zakresie przejąć $\mathrm{w}$ łańcuchu elektronicznym portale rezerwacyjne, jednak ich zakres oddziaływania i koordynacji będzie ograniczony, gdyż ich zadaniem jest dostarczanie klientom cząstkowych produktów dostosowanych do ich potrzeb i preferencji. Wydaje się zatem, że $\mathrm{w}$ nowoczesnej formie nie ma podmiotu, który mógłby przyjąć na siebie rolę integratora i koordynatora łańcuchów dostaw produktów turystycznych. To sprawia, że poszczególne ogniwa działają w warunkach większej niepewności, mogą mieć znaczne problemy z określeniem popytu, wykreowaniem strategii rozwoju czy podjęciem skutecznych działań promocyjnych. Brak koordynacji i ścisłej współpracy nie pozwala bowiem na skorzystanie z efektów synergii, które zauważyć można w dobrze zintegrowanych, tradycyjnych łańcuchach dostaw produktu turystycznego.

\section{Terroryzm i niestabilność polityczna jako czynniki wpływające na funkcjonowanie turystycznych lańcuchów dostaw}

Rozwój i funkcjonowanie turystyki w znaczący sposób sprzężone są z uwarunkowaniami geopolitycznymi oraz bezpieczeństwem na świecie. Turyści chcą bowiem podróżować do miejsc, w których mogą wypocząć bądź zwiedzić ciekawe obiekty, czując się przy tym bezpiecznie. Dlatego też wzrastające zagrożenie zamachami terrorystycznymi oraz niestabilność polityczna i ekonomiczna w wielu zakątkach świata stanowią dla zarządzania turystycznym łańcuchem dostaw istotne, a jednocześnie niezwykle trudne wyzwanie. Doskonałe tego przykłady można było zaobserwować w ostatnim czasie w Egipcie, Tunezji, Turcji oraz Grecji. W przypadku Egiptu i Tunezji niestabilność wywołana została rewolucjami, natomiast $\mathrm{w}$ Turcji - działaniami wojennymi na pograniczu turecko-syryjskim. We wszystkich tych krajach istnieje również duże zagrożenie zamachami terrorystycznymi. W Tunezji do takiego zamachu doszło w marcu 2015 roku w jednym z muzeów w Tunisie. Nieco inaczej wygląda kwestia Grecji, gdzie mamy do czynienia 
z kryzysem ekonomicznym, który jednak również może wpływać na zarządzanie turystycznym łańcuchem dostaw.

Potwierdzenie takiego stanu rzeczy przynoszą wyniki badania dotyczącego wakacyjnych wyjazdów Polaków, przeprowadzonego przez KPMGw sierpniu 2015 roku. $\mathrm{Z}$ badania wynika, iż ponad $60 \%$ respondentów, którzy zamierzali spędzić urlop w Grecji, Turcji bądź Tunezji, zmieniło swoje wakacyjne plany ze względu na niepewną sytuację panującą w tych krajach. Spośród tych badanych $87 \%$ postanowiło udać się $\mathrm{w}$ inne miejsca, a 13\% całkowicie zrezygnowało $\mathrm{z}$ wakacyjnego wyjazdu (KPMG 2015, s. 8).

Również dane Travelplanet $\mathrm{z}$ ostatnich kilku lat dotyczące najchętniej odwiedzanych przez klientów krajów ukazują, jak duże znaczenie ma sytuacja geopolityczna oraz groźba zamachów terrorystycznych. Udział pięciu najpopularniejszych krajów w strukturze wyjazdów klientów Travelplanet w latach 2010-2014 przedstawiono na Rysunku 5.

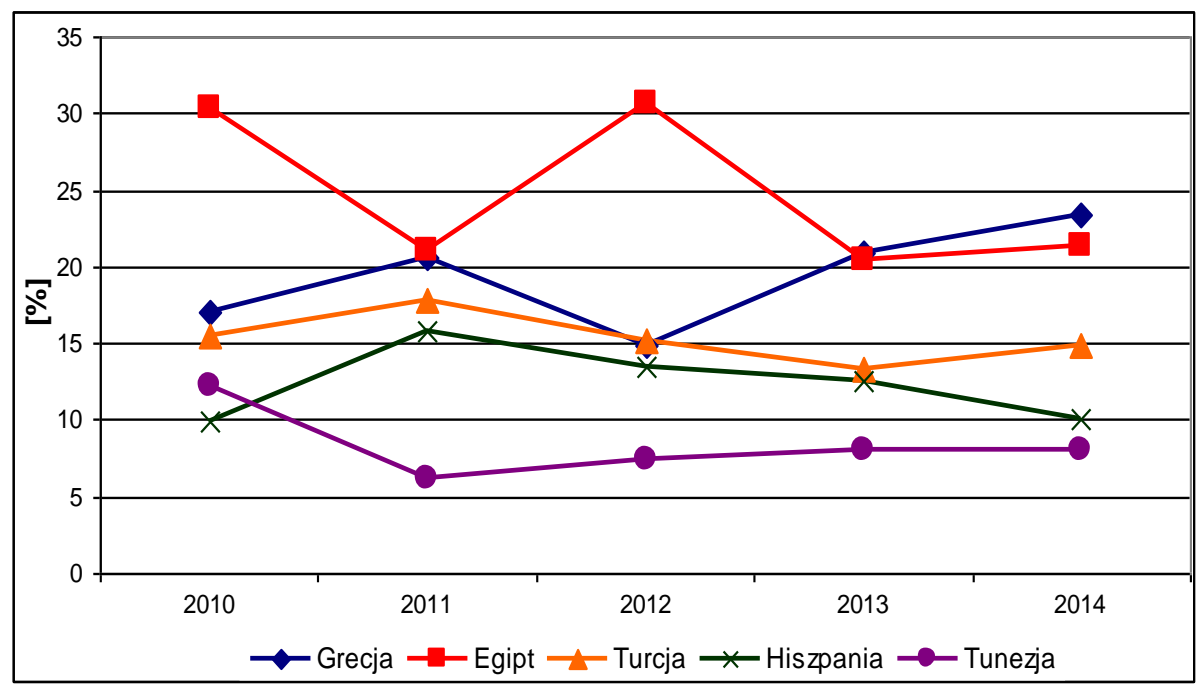

Rysunek 5. Udział pięciu najpopularniejszych krajów w strukturze zagranicznych wyjazdów wakacyjnych Polaków w latach 2010-2014

Źródło: Opracowanie własne na podstawie danych Travelplanet.pl

Największe wahania udziału w strukturze wyjazdów wakacyjnych polskich turystów zaobserwować możemy w przypadku Egiptu, co jest ściśle związane $\mathrm{z}$ wydarzeniami politycznymi mającymi miejsce w tym czasie. Pierwszy spadek zainteresowania Egiptem miał miejsce w roku 2011, kiedy w tym kraju rozpoczęła się rewolucja i obalono prezydenta Mubaraka. Po względnej stabilizacji w roku 2012, która zaowocowała przyciągnięciem podobnej liczby turystów jak przed rewolucją, krajem wstrząsnęły kolejne zamieszki. W 2013 roku miał miejsce wojskowy zamach stanu, w wyniku którego obalony został wybrany rok wcześniej prezydent. Od tego czasu popyt na wyjazdy do Egiptu nie wrócił do poziomu sprzed rewolucji. 
Do podobnej rewolucji doszło w 2011 roku w Tunezji i również w tym przypadku odbiła się ona niekorzystnie na popycie turystycznym, a co za tym idzie - na całym łańcuchu dostaw produktu turystycznego.

Warto również zauważyć, że niestabilność polityczna i zagrożenia zamachami $\mathrm{w}$ jednych krajach skutkują zwiększeniem popytu na produkty turystyczne oferowane w innych krajach. Doskonałym przykładem może być tu Hiszpania czy Grecja. Kraje te w związku z brakiem bezpieczeństwa, choćby w Egipcie czy Tunezji, przejęły sporą część popytu na wakacyjne wyjazdy Polaków w 2011 roku. O ile w przypadku Hiszpanii był to raczej krótki epizod, o tyle Grecja przyciąga coraz więcej turystów. Co ciekawe, nie przeszkadza jej w tym nawet fakt własnej niestabilności ekonomicznej, co jednak można tłumaczyć obniżką cen, która przyciąga mniej zamożnych turystów.

W obliczu tych wszystkich zagrożeń i braku stabilności touroperatorzy, jako główni integratorzy i zarządzający turystycznymi łańcuchami dostaw, stają zatem przed nie lada wyzwaniem. Ich zadaniem jest takie przeprogramowanie działalności, by nadal oferować klientom pakiety turystyczne spełniające ich oczekiwania, a jednocześnie zapewniające im poczucie bezpieczeństwa. Wszelkiego rodzaju niestabilności i zagrożenia terrorystyczne $\mathrm{w}$ miejscach recepcji turystycznej sprawiają, że w wielu wypadkach trzeba zlikwidować łańcuchy dostaw, lub chociaż czasowo zawiesić ich działalność. Rynek nie przyjmuje jednak próżni, zatem na ich miejsce trzeba powołać do życia nowe łańcuchy, dostarczające klientom inne produkty turystyczne. Powstaje tu zatem problem odpowiedniego doboru ogniw łańcucha, ustalenia zasad współpracy, nakreślenia strategii rozwoju oraz wspólnych działań promocyjnych, a także obliczenia kosztów funkcjonowania takiego łańcucha. Tego wszystkiego trzeba dokonać w stosunkowo krótkim czasie, by zaspokoić popyt przesunięty z zawieszonych bądź zlikwidowanych łańcuchów.

Takie przesunięcie popytu dla większości ogniw turystycznego łańcucha dostaw ma jednak kolosalne skutki. O ile touroperatorzy, zwłaszcza ci najwięksi, mogą sobie stosunkowo łatwo $\mathrm{z}$ tym poradzić, oferując po prostu inne produkty turystyczne, o tyle ogniwa znajdujące się w miejscach recepcji turystycznej nie mają już takiej możliwości. Dla nich likwidacja dotychczas funkcjonujących łańcuchów może przynieść katastrofalne skutki i doprowadzić je do upadku.

$Z$ dużą dozą pewności stwierdzić można, że przemiany polityczne oraz zagrożenia terrorystyczne stanowią obecnie największe wyzwania w zarządzaniu turystycznym łańcuchem dostaw. Wymuszają one bowiem działanie $\mathrm{w}$ warunkach niepewności, gdyż tak naprawdę nigdy nie wiadomo, w jakim miejscu może objawić się niebezpieczeństwo. Są oczywiście rejony bardziej i mniej na nie narażone, jednak przykłady zamachów we Francji pokazały, że nie da się ich przewidzieć. Ogniwa turystycznych łańcuchów dostaw, a w szczególności ich koordynatorzy, muszą stale śledzić zmieniające się otoczenie i w miarę możliwości elastycznie dopasowywać swoją strategię i działanie do zaistniałej sytuacji. 


\section{Podsumowanie}

Zarządzanie turystycznym łańcuchem dostaw jest zadaniem niełatwym i uwzględniać musi specyfikę samego produktu turystycznego, a przede wszystkim jego usługowy charakter i fakt, iż to konsument podróżuje do miejsca recepcji turystycznej. Skuteczne zarządzanie tym łańcuchem wymaga zwrócenia uwagi na takie kwestie, jak m.in.: zarządzanie popytem, dostawami i zapasami, relacje między ogniwami, rozwój produktów, koordynacja łańcucha oraz technologie informacyjne. W tradycyjnym łańcuchu dostaw produktu turystycznego rola integratora i koordynatora działań przypada touroperatorom, którzy odpowiedzialni są za kształtowanie pakietów turystycznych. Jednak rozwój Internetu i uzyskanie przez turystów możliwości samodzielnego kreowania własnych pakietów turystycznych prowadzi $\mathrm{w}$ pewien sposób do ograniczenia roli i znaczenia touroperatorów. To z kolei skutkować może problemami w całych łańcuchach dostaw, w których, z powodu braku koordynatora, dochodzić może do różnego rodzaju dysfunkcji.

Niezwykle istotnym wyzwaniem we współczesnym zarządzaniu turystycznym łańcuchem dostaw są przemiany geopolityczne i wzrastające zagrożenie terrorystyczne. Czynniki te sprawiają, że popularne dotąd pakiety turystyczne tracą na znaczeniu, konieczne jest zatem zmodyfikowanie lub zawieszenie działalności ich łańcuchów dostaw. W ich miejsce powołać trzeba nowe łańcuchy w innych obszarach recepcji turystycznej. To z kolei rodzić może, przynajmniej na początkowym etapie, problemy we współpracy i koordynacji działań poszczególnych ogniw. Ponadto touroperatorzy, jako koordynatorzy łańcucha, powinni opracować skuteczne mechanizmy reagowania w przypadku wystąpienia ewentualnego zagrożenia, by klienci w jak najmniejszym stopniu odczuli jego negatywne konsekwencje.

Liczni autorzy zagraniczni zajmujący się tematyką turystycznego łańcucha dostaw zwracają jeszcze uwagę na kwestie związane ze zrównoważonym zarządzaniem tym łańcuchem. W tym zakresie szczególna rola przypadać ma touroperatorom, którzy posiadają największe możliwości wpływania na pozostałe ogniwa łańcucha. Mogą oni zatem np. opracować pewne standardy działania przyjaznego środowisku i wymóc na współpracujących z nimi przedsiębiorstwach turystycznych podpisanie deklaracji stosowania tych standardów. Kwestie zrównoważonego rozwoju i ochrony środowiska są obecnie mocno akcentowane, a biorąc pod uwagę, że jakość środowiska naturalnego w miejscu recepcji turystycznej ma duży wpływ na zadowolenie turystów, nie powinno dziwić, że w zarządzaniu turystycznym łańcuchem dostaw przykłada się do nich coraz większą wagę.

\section{Literatura}

1. Buhalis D. (2008), Technologie informatyczne i telekomunikacyjne w turystyce, [w:] Pender L., Sharpley R. (red.), Zarządzanie turystyka, s. 282-298, PWE, Warszawa.

2. Fijałkowski D. (2003), Produkt turystyczny w ujęciu marketingowym a turystyka, ,Słupskie Prace Geograficzne", nr 1, s. 81-90.

3. KPMG w Polsce (2015), Wakacyjne wyjazdy Polaków, KPMG, Warszawa. 
4. Kusa R. (2009), Analiza łańcucha dostaw produktu turystycznego, [w:] Pyka J. (red.), Konkurencja i kooperacja $w$ strategiach zarzadzania organizacjami, s. 129-139, TNOiK Oddział w Katowicach, Katowice.

5. Ministerstwo Sportu i Turystyki (2016), Turystyka $w$ Polsce w 2015. Ulotka statystyczna, Warszawa.

6. Rapacz A. (2007), Przedsiębiorstwo turystyczne, Difin, Warszawa.

7. Sigala M. (2008), A Supply Chain Management Approach for Investigating the Role of Tour Operators on Sustainable Tourism the Case of TUI, „Journal of Cleaner Production”, Vol. 16, s. 1589-1599.

8. Surowiec A. (2012), Pomiar osiagnięć w tańcuchu dostaw przy wykorzystaniu zrównoważonej karty wyników, „Zeszyty Naukowe Politechniki Częstochowskiej. Zarządzanie”, nr 7, Kościelniak H. (red.), Sekcja Wydawnictw Wydziału Zarządzania Politechniki Częstochowskiej, Częstochowa, s. 91-100.

9. Ślusarczyk B., Szajt D. (2013), Globalizacja jako element wzrostu konkurencyjności, „Zeszyty Naukowe Politechniki Częstochowskiej. Zarządzanie”, nr 10, Sekcja Wydawnictw Wydziału Zarządzania Politechniki Częstochowskiej, Częstochowa, s. 98-110.

10. Tapper R., Font X. (2004), Tourism Supply Chains. Report of a Desk Research Project for The Travel Foundation, Leeds Metropolitan University, Leeds.

11. Tigu G., Calaretu B. (2013), Supply Chain Management Performance in Tourism. Continental Hotels Chain Case, ,Amfiteatru Economic”, Vol. 33, s. 103-115.

12. Zhang X., Song H., Huang G.Q. (2009), Tourism Supply Chain Management: A New Research Agenda, ,Tourism Management”, Vol. 30, s. 345-358.

\section{NEW CHALLENGES IN TOURIST SUPPLY CHAIN MANAGEMENT}

Abstract: The purpose of this article is to present the challenges faced by the coordinators and integrators tourism supply chains due to the rapidly changing environment. At the beginning is characterized tourist product, then are presented the issues of the tourism supply chain and its management including elements that have the greatest impact on the efficiency of this management. Finally, are defined and characterized the two biggest challenges in supply chain management of the tourist product, which are changing the structure of the chain associated with the development of the Internet and the unstable geopolitical situation and the threat of terrorist attacks in tourist regions.

Keywords: tourist product, tourist supply chain, tourist supply chain management 